\title{
The Women of the Globe: A Retrospective Quest for the Unified Gender Discrimination
}

\author{
Amrutha Modcy \\ Assistant Professor \\ Department of English \\ Holy Cross Institute of Management and Technology \\ Calicut, Kerala, India \\ ammumodcy@gmail.com
}

\begin{abstract}
The works written by women focus on the discrimination they were subjected to from the primordial times either through the various mythical stories or through the patriarchal ideologies prevalent in the society. The shift in the marginal positioning of women was bought into question through the feminist movements and the literary works of women. Though the literary works of women aimed at a new understanding of the position of women it left out the aim of uniting the narratives of women from different classes. The elimination of these class differences and creation of a common understanding bereft of any class, nation or race barriers is necessary. This act of bringing together the narratives of women from different classes helps in developing a universal or global understanding among women. The attempt made by Margaret Atwood in her novella The Penelopiad to narrate the mythical story of Homer's Odyssey from the point of view of Penelope and the twelve maids blurs the margin of class discrimination and calls for a global understanding. The novella focuses on the point that it is only through the "act of looking back" from a new position that reveals various misunderstandings we lived through.
\end{abstract}


Keywords- Transnationalism, Revisioning, Feminism, Decentralising, Gender performativity

Introduction

Transnationalism is defined as the diffusion and extension of social, political and economic processes in between and beyond the jurisdictional boundaries of nation-states. The researches in this field are found to focus on shifting the analysis from the individual to the global system. The works by women focus on the discrimination they were subjected to from the primordial times either through the various mythical stories or through the patriarchal ideologies prevalent in the society. The works aim at questioning the discriminatory actions forced upon the women that marginalize them into the boundaries. The women writers like, Simon De Beauvoir, Adrienne Rich and so on advocated the need for the women to tell their own stories in order to subvert their discriminated positions in the society.

The transnational feminists developed the practice of activist movements across the globe that work together to understand the role of gender, in critiquing the resisting structures of patriarchy. It resists the utopian idea of global sisterhood and works to lay the groundwork for more productive and equitable social relation among women across borders and cultural contexts. The idea of global sisterhood was rejected by the transnational feminists as the western feminists believed that all women face or undergo the similar situations.

This issue of global sisterhood is evident through the different narratives as each narratives focused on the condition of women in a particular class or culture or even race. Though the literary works of women aimed at a new understanding of the position of women it left out the aim of uniting the narratives of women from different classes. The elimination of these class differences and creation of a common understanding bereft of any class, nation or race barriers is necessary. This act of bringing together the narratives of women from different classes helps in developing a universal or global understanding among women and 
will thereby challenge how people from different cultures understand what being a "woman" is. Inderpal Grewal and Caren Kaplan says in their work that the transnational feminist is working "to construct such a terrain of coalition and cooperation", however, we "have to rearticulate the histories of how people in different locations and circumstances are linked by the spread of and resistance to modern capitalist social formations" even as their experiences of these phenomena are not at all the same or equal (18).

The writings of women portray the determination to narrate their own stories and to create a new understanding. In the earlier writings of women the narratives focused on telling a story from the women's perspective that open a clear understanding of the position of women in the society. These writings indeed made it possible for the feminists to voice out their rights and these narratives helped the women to talk about their positioning in the society.

The women writers found the need to retell already known stories which are said from the point of view of the patriarchal society in order to subvert and question the discrimination they face. This act of revisioning is termed as the "act of looking back with fresh eyes" that is to enter the already known story from a new entry point which for the women writers was a chance to exhibit their view of the story (Rich 18). By retelling the mythical stories from the women's point of view the writer's attempts to create a universal understanding of what it is to be a woman. These new interpretations force readers to a new understanding of the story and how the women are constrained within the stereotypes created by them.

In order to bring in this new understanding the women writers had chosen the myths and bestowed the power of narration to the hands of women characters whose narratives were sidelined. Myths which are the stories of the primordial times are found to be the building block that creates the culture of a particular society. These mythical stories are considered as the reference points for determining the behavioral pattern within the society and there by 
creates the class, gender binaries within the society. Thus myths were the appropriate tool chosen by the women in order to break free from the fretters of life. The main feature of myth is it's the multiple interpretations and retellings, which helps people to achieve a new understanding of their fragmented and tragic world through "transfiguring" it by raising a simple question of "What if?" (Armstrong 7). This simple question has in it the ability to throw open various loose endings in the stories that we already know thereby making it possible to have a new and deeper understanding of the world we live in.

Margaret Atwood in her novella The Penelopiad retells the story of the Homer's Odyssey from the point of view of Penelope and the twelve maids. The narrative brings out the instances from the myth from the point of view of the women who were sidelined there by decentralizing the narrative. By bringing together the narration of women from different strata of society, Atwood exposes the fact that "stories of myth are not in the least concerned about the ordinary people who make the lives of the kings and heroes possible and thus challenges us to reassess the consequences of the identifications we make when we read modern retellings of ancient myth" (Braund 203).

The novella incorporates the narrative voices of the twelve unnamed maids who do not speak in Homer's Odyssey and whose hanging by Odysseus is treated as unimportant. Thus Atwood's intention of giving importance to the emotions and experiences of the maids is her way of asserting the importance to the narratives from the margins, addressing not just issues of gender but also those arising out of the intersection of class and gender. Through the incorporation of two narratives in the novella, Atwood challenges the hegemonic monopoly of a single narrative voice and provides a deeper understanding of the already known story. Indeed by focusing upon the emotions of women through the projection of the various occurrences Atwood instills a need for re-evaluation of the gender roles they are confined to. 
In most of the women's literature we find the narrative focusing on the situation of women within a particular society or a class but here by bringing together the narratives from different stratas of society Atwood initiates a realization of the ignorance faced by the third world people. Through Penelope's narrative the readers are given an insight into the guilt of not helping the maids have their justice. Penelope is found to be desperate to clear out the hatred the maids have towards her but this revelation or change of attitude in Penelope is seemed to have developed as the narration takes place from the underworld. Penelope was able to voice out the injustices carried out towards the maids in her narration as she doesn't fear any aftermaths.

\section{Conclusion}

It is this freedom of being in their lives after death that makes the narrators strongly voice out their anger against the stereotypes and discrimination they face on the basis of gender and class. Penelope's compassion towards the maids is evidently described through her narration when she describes how these maids were deprived of the right to marriage as well as sex. Penelope refers to the maids as her sisters as they helped her to be away from the suitors and also to run the kingdom in the absence of Odysseus. The sisterhood they shared was not acknowledged by Penelope in Odyssey and this had led to the brutal murder of the twelve maids. So this can be seen as an attempt of Atwood to instill the compassion and universal collaboration of women irrespective of the differences in class, state or race which the transnational feminists try to achieve. The idea given to the readers is not "whether to repeat" the gender roles assigned by the society "but how to repeat or, indeed, to repeat and, through a radical proliferation of gender, to displace the very gender norms that enable the repetition itself' and analyze the way woman are seen across boundaries (Butler 203). 


\section{Works Cited}

Armstrong, Karen. A Short History of Myth. New Delhi: Penguin Books, 2005.

Atwood, Margaret. The Penelopiad. Haryana: Penguin Books, 2005.

Braund, Susanna. "“We're Here too, the Ones without Names': A Study of Female Voices as Imagined by Margaret Atwood, Carol Ann Duffy, and Marguerite Your cenar.” Classical Receptions Journal 4.2 (2012): 190-208.

Butler, Judith. Gender Trouble: Feminism and the Subversion of Identity. New York: Routledge, 1990.

Grewal, Inderpal and Caren Kaplan. Scattered Hegemonies: Postmodernity and Transnational Feminist Practices. Minneapolis: University of Minnesota Press, 1994. Rich, Adrienne. "When We the Dead Awaken: Writing as Re-vision." Women Writing and Teaching 34.1 (1972): 18-30. 